\title{
Preliminary Phytochemical Analysis and In vitro Anti-helmenthic activity of Achyranthes aspera Leaf extract
}

\author{
Kamal Hasan', Thangavelu Lakshmi ${ }^{2 *}$ and Thirumalai Kumaran Rathinam ${ }^{3}$ \\ 'Bachelor of Dental Surgery, Saveetha Dental College, Saveetha University, Chennai, India. \\ 2Department of Pharmacology, Saveetha Dental College, Saveetha University, Chennai, India. \\ ${ }^{3}$ Department of Pharmacy, Faculty of Pharmacognosy, Sree ramachandra University, Chennai, India.
}

\begin{abstract}
Objective: To evaluate the preliminary phytochemical analysis and in vitroAntihelmenthic activity of leaf extract of Achyranthes aspera. Background: Achyranthes aspera is an annual, stiff-erect herb found commonly as a weed throughout India. The leaf ethyl acetate extract showed high larvicidal activity on the tick larvae of Rhipicephalus. It strengthen the liver and kidneys, strengthening muscles, tendons and bones, anti-inflammatory, anti-toxin, urine laxative, normalize menstruation, hemostatic, ease childbirth. Chemical Ingredients includes Akirantin, glokosa, galactose, reilosa, ramnosa, and alkaloids. Hentriakontan, sapogenin, Betaine, ecdysterone, triterpenoid saponins. Methods: Preliminary phytochemical analysis was done by adopting the method of Evans. Antihelmenthic assay is performed by standard protocol. Result: The present study reveals the presence of few secondary metabolites and the extract exhibitspotent Antihelmenthic activity. Conclusion: From the present study it can be concluded that Achyranthes aspera leaf extract possessed marked in vitro Anti helminthic effect.
\end{abstract}

Key words: Achyranthes aspera, Anti-helmenthic, Anti-inflammatory, Laxative, Phytochemical.

\section{SUMMARY}

- Achyranthes aspera leaf showed prominent anti-helmenthic activity.

- Achyranthes aspera leaf showed presence of phytochemical constituents.

- Achyranthes aspera is used in management of inflammatory disorders,

cough, bronchial asthma.

- Achyranthes aspera leaf extract were reported to posses thyroid stimulating and antiperoxidative properties.

- Achyranthes aspera strengthen the liver and kidneys, strengthening muscles, tendons and bones, anti-toxin, urine laxative, normalize menstruation, hemostatic, ease childbirth.

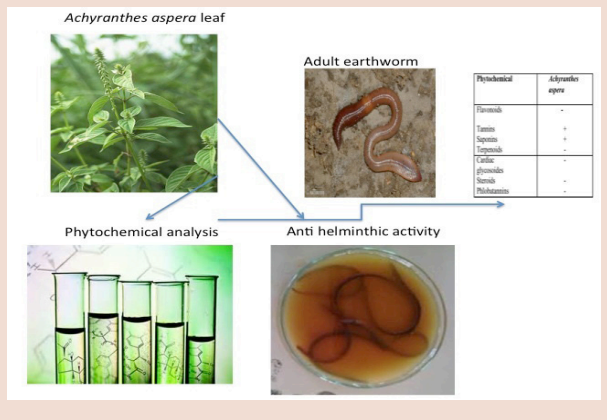

PICTORIAL ABSTRACT

Abbreviations used: A. aspera: Achyranthes aspera, DMSO: Dimethyl sulfoxide.

Correspondence:

Ms. Thangavelu Lakshmi, Assistant professor, Department of Pharmacology, Saveetha Dental College and Hospitals, Chennai, T.N, India.

Phone no: 09884708887

Email: lakshmi085@gmail.com

DOI : 10.5530/pj.2015.6.14

\section{INTRODUCTION}

Achyranthes aspera L. (Amaranthaceae) is distributed as weed throughout India, tropical Asia and other parts of the world. ${ }^{1-3}$ The plant is a popular folk remedy in traditional system of medicine throughout the tropical Asian and African countries. It grows throughout the tropical and warmer regions throughout the world. ${ }^{4-6}$ The weed is also found in many other countries of Asia as well as Africa, America, Europe and Australia. ${ }^{7,8}$ The plant is reported to be used as antimicrobial, larvicidal, antifertility, immunostimulant, hypoglycemic, hypolipidemic, antiinflammatory, antioxidant, diuretic, cardiac stimulant, antihypertensive, anti-anasacra, analgesic, antipyretic, antinoiceptive, prothyrodic, antispasmodic, antihelminthic, etc for various purpose. ${ }^{9}$

\section{MATERIAL AND METHODS}

\section{Plant Material}

Achyranthes aspera where collected from Hosur Tamil nadu. Leaves were dried in open air under shade. $100 \mathrm{~g}$ of dried Achyranthes aspera was used in extraction Method. Plant material was authenticated by NISCAIR, New Delhi. The voucher specimen were stored in M/s. Green Chem, Bangalore For further use.

\section{Extraction protocol}

The powdered dried leaf of Achyranthes aspera extracted with $80 \%$ Ethanol, at 55 to $60^{\circ} \mathrm{C}$ temperature, for 2 hours, in a round bottom flask with condenser attached. Collect the extract. Repeat extraction with $80 \%$ Ethanol. Collect the extract. Marc was again extracted with 50\% ethanol twice at a temperature of about 55 to $60^{\circ} \mathrm{C}$, for 2 hours. The extracts are distilled. Solvent was removed under pressure in a Buchi Rotary evaporator at 30$35^{\circ} \mathrm{C}$ to obtain a concentrate. The concentrate was chilled at temperature about $6-10^{\circ} \mathrm{C}$ for a period of about $7-8$ hours to remove the resinous matter. Chilled concentrate was filtered. Filtrate was collected. Filtrate was evaporated to dryness under reduced pressure in a Buchi Rotary Evaporator (Switzerland) at $50-55^{\circ} \mathrm{C}$. Powdered A. aspera leaf extract was obtained.

\section{Drugs and chemicals}

All the chemicals and reagents were procured from HI media (Mumbai, India). All the chemicals were of analytical grade. The drug Albendazole was procured from Sigma aldrich.

\section{Phytochemical analysis}

The ethanolic extract so obtained from the dried leaf powder of $A$. aspera, were tested for the presence and absence of the phytochemicals 
-Tannins, Phlobatannins, Saponins, Flavonoids, Terpenoids, Phenols, Cardiac glycosides and Steroids according to method described by Evans. ${ }^{10}$ The results are depicted in Table 1 .

Table 1: Phytochemical analysis of Achyranthes aspera leaf

\begin{tabular}{cc}
\hline Phytochemical & Achyranthes aspera \\
\hline Flavonoids & - \\
Tannins & + \\
Saponins & + \\
Terpenoids & - \\
Cardiac glycosoides & - \\
Steroids & - \\
Phlobatannins & - \\
\hline
\end{tabular}

$+=$ Presence; $-=$ Absence.

\section{Experimental model}

Adult earthworms of the genus and species, Phertima posthuma, were collected (due to their anatomical and physiological resemblance with the intestinal roundworm parasites of human beings) from moist soil and washed out of sand. Four groups of approximately equal size earthworms Consisting of six earthworms in each group were used for the present study. ${ }^{11}$

\section{Anthelmintic Evaluation}

\section{Standard Drug}

Albendazole is taken as standard drug and the concentration of the standard drug was prepared in dissolving DMSO to give $80 \mathrm{mg} / \mathrm{ml}, 60 \mathrm{mg} /$ $\mathrm{ml}, 40 \mathrm{mg} / \mathrm{ml}$ and $20 \mathrm{mg} / \mathrm{ml}$ concentration.

\section{Antihelmenthic assay}

Four groups of approximately equal size earthworms consisting of six earthworms in each group were used for the present study, Albendazole, Ethanolic extract $(20 \mathrm{mg} / \mathrm{ml}, 40 \mathrm{mg} / \mathrm{ml}, 60 \mathrm{mg} / \mathrm{ml}$ and $80 \mathrm{mg} / \mathrm{ml}$ concentration). Observations were made for the time taken to paralysis and death of individual worms. Paralysis was said to occur when the worms do not revive even in normal saline. Death was concluded when the worms lost their motility followed with fading away of their body color. ${ }^{12-16}$

\section{RESULT AND DISCUSSION}

Helminths are parasitic worms. They are the most common infectious agents of humans in developing countries and produce a global burden of disease including malaria and tuberculosis. ${ }^{17}$ These same helminthiasis markedly altered the course of modern twentieth century world history. Today, it is estimated that approximately one-third of the almost three billion people that live on less than two US dollars per day in developing regions of sub-Saharan Africa, Asia, and the Americas are infected with one or more helminth. ${ }^{18}$

The most common helminthiases are those caused by infection with intestinal helminths, ascariasis, trichuriasis, and hookworm, followed by schistosomiasis. The treatment given to treat helminthiasis such as Albendazole was well tolerated and did not produce any significant side-effects. Single dose albendazole appears to be appropriate for mass chemotherapy to control intestinal nematode infections in highly infected communities ${ }^{19}$ Herbal drugs are commonly used in eradication of various infections. It is popularly used in traditional system of medicine. Lots of herbal drugs have the potency to inhibit the adult erathworms, roundworms and hookworms for worm infestations, herbal drugs have been observed as an effective remedy.
Achyranthes aspera stem extract has been proved to possess the anti helmenthic activity, Hence A.aspera leaf extract were tested at various concentation against adult earthworm.

The ethanolic leaf extract of Achyranthes aspera showed significant anthelmintic activity. The result of anthelmintic activity of alcoholic leaf extract of $A$. aspera on earthworms (Phertima posthuma) were given in Table 2. It was concluded from the study that the extract showed marked anthelmintic activity than the standard drug albendazole. Standard drug albendazole is showing moderate activity.

Table 2: Anti helminthic assay of Achyranthes aspera leaf against Phertima posthuma

\begin{tabular}{cccc}
\hline Drug & $\begin{array}{c}\text { Concentration } \\
\mathrm{Mg} / \mathrm{ml}\end{array}$ & $\begin{array}{c}\text { Paralysis time in } \\
(\mathrm{min} .)\end{array}$ & $\begin{array}{c}\text { Death time in } \\
\text { (min.) }\end{array}$ \\
\hline \multirow{3}{*}{$\begin{array}{c}\text { Ethanolic extract } \\
\text { of }\end{array}$} & 20 & $68.60+0.26$ & $84.2+0.3$ \\
A. aspera & 40 & $52.32+1.08$ & $68.0+0.86$ \\
& 60 & $48.30+0.68$ & $60.13+0.76$ \\
& 80 & $42.18+0.26$ & $38.46+0.23$ \\
Albendazole & 20 & $11.00+4.50$ & $22.00+9.00$ \\
& 40 & $11.60+4.75$ & $45.00+17.00$ \\
& 60 & $14.10+5.77$ & $47.16+19.23$ \\
& 80 & $14.30+5.86$ & $49.16+20.00$ \\
\hline
\end{tabular}

\section{CONCLUSION}

In conclusion, the traditional use of leaf of Achyranthes aspera as an anthelmintic drug have been confirmed as the ethanolic extract of $A$. aspera displayed activity against the worms used in the study. Further studies are required to establish the mechanism(s) of action are required.

\section{ACKNOWLEDGEMENTS}

The author's wish to acknowledge, Green Chem herbal extracts formulations Bangalore for providing the herbal extract as a gift sample and the management, Saveetha Dental College and Hospitals for providing all the necessary facilities and encouragement.

\section{CONFLICT OF INTEREST}

The author declares no conflict of interest.

\section{REFERENCES}

1. Shibeshi W, Makonnen E, Zerihun L, Debella A. Effect of Achyranthes aspera $\mathrm{L}$. on fetal abortion, uterine and pituitary weights, serum lipids and hormones. African Health Sciences 2006; 6(2): 108-12.

2. Joshi AC. Dedoublement of stamens in Achyranthes aspera Linn. J. Indian bot. Soc. 1932; 11(4): 335-9.

3. Kajale LB. Embryology of Achyranthes aspera Linn. Proceedings: Plant Sciences 1937; 5(5): 195-205.

4. Girach RD, Khan ASA. Ethnomedicinal uses of Achyranthes aspera leaves in Orissa (India). Int J Pharmacogn. 1992; 30(2): 113-5.

5. Liersch Bkher. Achyranthes. In: Haensel R, Keller K, Rimpler G, Schneider G (eds) Hagers Handbuch der Pharmazeutischen Praxis V. Springer-Verlag, Berlin; 1992. 54-9.

6. Hooker JD. The Flora of British India. 4, L. Reeve \& Co. Ltd, Kent; 1885. 713-30. 7. Prain D. Bengal Plants. 4, Botanical Survey of India. Calcutta; 1963. 646-55.

8. De Lange PJ, Scofield RP, Greene T. Achyranthes aspera (Amaranthaceae), a new indigenous addition to the flora of the Kermadec Islands group. New Zealand J. Bot. 2004; 42(2): 167-73.

9. Shafique S, Javaid A, Bajwa R, Shafiqe S. Biological control of Achyranthes aspera and Xanthium strumarium in Pakistan. Pak. J. Bot. 2007; 39(7): 2607-10.

10. Evans WC. Trease and Evans Pharmacognosy 14 Edn. WB Saunders Company. London; 1996.

11. Blakemore R. Diversity of exotic earthworms in Australia-status report. Transac- 
tions of the Royal Zoological Society of New South Wales 1999; 99: 182-7.

12. Dwivedi SN. Herbal remedies among the tribals of Sidhi District of Madhya Pradesh. J. Econ. Tax. Bot. 2004; 20(3): 675-87.

13. Gunasekhararan R, Divyakant A, Senthilkumar KL. Anthelmintic activity of bark of Neolamarckia cadamba Roxb. Ind. J. Nat. Prod. 2006; 22(1): 11-3.

14. Kosalge SB, Fursule RA. Investigation of in vitro Anthelmintic Activity of Thespesia Lampas (cav.). Asian J. Pharm. Clin. Res. 2009; 2(2): 69-71.

15. Khadatkar SN, Manwar JV, Bhajipale NS. In vitro Anthelmintic Activity of Root of Clitoria Ternatea Linn. Phcog. Mag. 2008; 4(13 Suppl): 148-50.
16. Mali RG, Wadekar RR. In Vitro Anthelmintic Activity of Baliospermum Montanum Muell. Arg Roots Indian J. Pharm. Sci. 2008; 70(1): 131-3.

17. Faust EC, Russell PF, Jung RC. Craig and Faust's clinical parasitology. $8^{\text {th }}$ edition. Philadelphia, Lea \& Febiger; 1970. p. 251.

18. Cox FEG. History of human parasitology. Clin. Microbiol. Rev. 2002; 15(4): 595-612.

19. Hotez PJ, Ottesen E, Fenwick A, Molyneux D. The neglected tropical diseases: the ancient afflictions of stigma and poverty and the prospects for their control and elimination. Adv. Exp. Med. Biol. 2006; 582: 23-33.

\begin{tabular}{|c|c|}
\hline & ABOUT AUTHORS \\
\hline 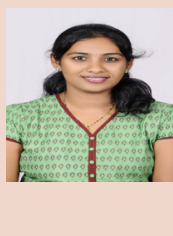 & $\begin{array}{l}\text { Ms. Thangavelu Lakshmi: Is an Assistant professor at the Department of Pharmacology, Saveetha Dental College and Hospitals, } \\
\text { Saveetha University, Chennai, Tamilnadu, India. Her research interest includes Pharmacognosy, Pharmacology, Phytotherapy, Toxicology, } \\
\text { and Pharmaceutical sciences. She has more than } 50 \text { nos. of Publications in peer reviewed indexed national and international journals. } \\
\text { She is a peer reviewer in various journals. She is a IRCA registered Lead auditor for QMS ISO } 9001: 2008 \text { certification. She is an editorial } \\
\text { board member in International journal of pharmacy and pharmaceutical sciences, Internationale pharmaceutica sciencia, IBIMA publish- } \\
\text { ers, USA. Ms.Lakshmi is also alife member of Indian pharmacological society, Society of Pharmaceutical education and research (SPER), } \\
\text { Indian association of biomedical scientist (IABMS), Society of Toxicology (STOX) and Society of Ethno pharmacology. }\end{array}$ \\
\hline
\end{tabular}

